good-looking but careless as to dress, the brim of his straw hat being half broken off. In the opposite corner was a very quiet young unassuming man. I found that the first was John Freeman and the other the late Sir Alexander Fleming; both, of course, were to become colleagues of the great Sir Almroth Wright who founded the Inoculation Department of St. Mary's Hospital, later to be known as the Wright-Fleming Institute.

Freeman graduated B.Ch. in 1905, and D.M. in 1907, and married in the same year Violet Hadden, of Murtle, Aberdeenshire. There were three sons and a daughter. Salaries of hospital workers in those days were very small or non-existent, and therefore private practice from Sir Almroth Wright downwards was encouraged. J. F. acquired a large house in Devonshire Place and soon had a big practice there as well as running a large clinic in the Inoculation Department at St. Mary's. Certain colleagues, including Sir Alexander Fleming, Leonard Colebrook, Parry Morgan, Prof. Pannett and myself, among others, were privileged to consult from that address, and this was a happy house, for the hospitality and geniality shown to all colleagues by J. F. and his wife were excellent.

In 1908 Freeman joined Leonard Noon in the study of hay fever. It was known by Dunbar's researches that extract of pollen could produce the disease in a hay-fever subject, and would cause reactions if injected into the skin. Dunbar thought this was due to toxin and tried to get a passive immunity by injecting anti-sera from immunized horses. Freeman and Noon produced an active immunity by making a series of pollen injections of graduated strength. Noon died all too soon of tuberculosis in 1911, leaving Freeman to develop and carry on his work, particularly in a large clinic at St. Mary's, where Freeman devoted a great deal of time as well as practising in private.

Early in the First World War, Freeman, as a colonel in the Russian Army, went to Galicia to collect material for the preparation of large quantities of cholera vaccine, and after that joined Wright and his workers in the laboratories at the Casino in Boulogne.

After this War he became clinical bacteriologist to the Hospital and also lecturer in bacteriology.

In the Second World War he organized a practical service in blood transfusions, and spent a great deal of energy, not to mention money, in running it in a most efficient manner.

But his life work was undoubtedly the study of hay fever and allergic disorders, and as a result forty years of experience and obscrvation were published by him in 1950 in his erudite and at times amusing book called Hay-Fever, a Key to the Allergic Disorders, dedicated to "L. N. This account of my Stewardship".

A. B. Porteous

\section{Prof. H. Deuel}

Wixh the untimely death of Hans Deuel at the age of forty-six in Berne, Switzerland, agricultural chemistry lost one of its most versatile and active personalities. H. Deuel was born in Leipzig in 1916, where he attended the König-Albert-Gymnasium. $\mathrm{He}$ later moved to Zürich and studied agriculture at the Swiss Federal Institute of Technology, where he remained for the rest of his life. He graduated in agricultural chemistry with a Ph.D. degree and became full professor and head of the Department of
Agricultural Chemistry in 1949. In this position he succeeded his former teacher, Prof. H. Pallmann, who was elected president of the Swiss Federal Institute of Technology.

H. Deuel was primarily interested in the chemistry and properties of polysaccharides. He tried to relate specific properties (for example, gelation, complex formation) with structural features of these compounds. His investigations on plant gums and above all pectic substances are well known among specialists throughout the world. Through his many publica. tions he contributed to all aspects of pectin chemistry and became one of the foremost experts on pectio substances.

In 1954 he published his work on the use of crosslinked neutral polysaccharides for the separation of high-molecular-weight from low-molecular-weight compounds. This method has been rediscovered and developed by Swedish workers and named 'gel filtration'; it is now in general use in many labora. tories.

Another field of active interest of $\mathrm{H}$. Deuel was soil science, where he made many valuable contributions to the chemistry of soil constituents. His investigations on ion exchange properties of natural and synthetic ion exchangers are well known and led him to a study on the ion exchange properties of plant roots. H. Deuel also prepared new organic derivatives of clays and silica gel. His observations on the degradation of clays and silica gel by 0 -diphen. ols shed new light on possible reactions involved in organic weathering. In recent years he has also been actively engaged in an investigation of carbohydrates in soils and on the chemistry of humic substances.

H. Deuel's life was fully devoted to his scientific interests which he pursued with enthusiasm and vigour. His knowledge of the literature was truly outstanding, and he always gave freely of his vast store of knowledge. To his co-workers and students he was an inspiring and ever-helpful teacher. $H$. Deuel liked vivid discussions; his mind was very critical but paired with a good sense of humour. Ho was not only a very capable and respected scientist but also a man of high moral standing and humanistic education. He will always be warmly remembered by all who knew him.

H. Deuel is survived by his widow and two sons.

\section{H. NEUKOM}

\section{Mr. F. C. Cooke}

Frank Cyril Cooke, editor of World Crops, died on January 11 at the age of sixty-three. His training as a chemist specializing in soap-making and the manufacture of alkaline products fitted him for his first appointment with Unilever. In 1929 he accepted an Empire Marketing Board appointment in Malaya as assistant chemist for Copra Investigations. Later, he joined the Malayan Department of Agriculture as chemist, coconut products. An assiduous investigator, he rapidly became conversant with all aspects of the subject and devoted his attention particularly to the improvement of copra production on small holdings. Eventually he devised a simple type of drying kiln-which has achieved world-wide recog. nition-capable of producing high-grade copra.

In 1946, Frank Cooke became canning research officer, Malaya, in which capacity he investigated the canning of pineapples and other products. This work contributed materially to the rehabilitation of the 
pineapple canning industry, which had suffered a tromondous setback during the Japanese occupation of the country.

In 1949 he was appointed director of the Coconut Research Institute of Ceylon, a post he hold for seven years, and which gave him an opportunity of proving that he possessed considerable administrative ability. As an acknowledged authority on coconuts and pineapples, he visited a number of countries to study local problems and to give advice. He published many valuable reports and articles, notably on coconuts in the Philippines, Ceylon and the Seychelles, and on pineapples in Hawaii. Ho also founded and edited for a number of years the Ceylon Coconut Quarterly.

Cooke returned from the East in 1957 to become editor of World Crops, a post he held with great distinction until his death. He brought to his editorial duties a wide knowledge of agriculture and chemical engineering and a new-found ability to exrress deeply felt convictions with force and clarity. Throughout his career he did much to assist agriculture in the tropics, especially in the less-developed countries.

Frank Cooke saw active service in both World Wars. In the first he served for three years in Mesopotamia. Earlier in his career in Malaya he joined the Malayan Volunteer Forces. As a commissioned officer in this Unit he fought in the War in Malaya and was taken prisoner in Singapore. During the post-war emergency, advantage was taken of his intimate knowledge of the country when he guided forcos in jungle oporations against communist bandits. D. H. GRIST

\section{NEWS and VIEWS}

\section{Inorganic Chemistry at Manchester:}

Prof. F. Fairbrother

Prof. F. Fairbrother, who retires this year from his chair of inorganic chemistry in the University of Manchester, has spent almost the whole of his working life there since he entered the University as a Seaton Scholar in 1912. He graduated in 1915, with firstclass honours in chemistry, and was appointed to the staff in 1919 . He became reader in inorganic chemistry in 1941 and has held his present chair since 1960 . During 1936-37 ho held a Leverhulme Fellowship at the University of California and the California Institute of Technology. He has been for many years an examiner, and more recently chief examiner in chemistry, for the Joint Matriculation Board. His research, initially in the field of colloid chomistry, soon turned towards the measurement of dielectric polarization and its significance in inorganic chemistry. His principal interests have beon in the gonoral nature of electrolytic dissociation processes, and his work has included studies on the dipole moments of hydrogen halides and cyanogen halides, and the earliest recognition of the charge separation in iodine molecules caused by donor solvents. His demonstra. tion of equilibrium halogen exchange between certain organic chlorides and aluminium chloride, and so of the importance of carbonium ions in Friodel-Crafts reactions, was an important step forward in the study of that reaction. Moro recently he has worked on the chomistry of niobium and tantalum. Prof. Fairbrothor was a pioneer in the study and teaching of inorganic chemistry on a physical basis. While jnorganic chemistry suffered neglect in many universitios, it remained an important integral part of the Manchestor School of Chemistry. His labours have provided a sound basis for further advance.

Prof. J. Lewis

Prof. Fatrbrother is succeeded by Dr. J. Lewis, at present reador in inorganic chemistry in University College, London. Dr. Lewis graduated with first-class honours from the former University College, Nottingham, in 1949. 'Three years later he went to Shoffield as assistant lecturer, transferring in 1956 to the Imporial College of Science and Tochnology, and in 1957 to University College, where he was promoted to a readorship last yoar. During 1960 ho hold a professorship in the Massachusotts Institute of Tech- nology, and while there travelled extensively in the United States. His early work was concerned with solutions in liquid dinitrogen tetroxide, and was followed by a study of the surface properties of liquid sodium. In recent years his main work has been in the field of transition metal complexes, and especially the application of magnetic and spectroscopic techniques to the elucidation of their structures. He is at present following up his early interest in metallic nitrosyls, developed while he was still at Nottingham.

Veterinary Physiology at Edinburgh : Prof. A. Iggo

Dr. Ainstex IGGo has been appointed to the newly instituted chair of veterinary physiology at the Royal (Dick) School of Veterinary Studies, University of Edinburgh. Dr. Iggo was trained in New Zealand in agriculture and went to Sir John Eceles at Dunedin, whero ho obtained a B.Sc. with first-class honours. He worked on the movements of the stomach in ruminants at the Rowett Research Instituto, Acerdeen, in 1951, and when he went to the Department of Physiology in the University of Edinburgh in $\mathbf{1 9 5 2}$ he isolated single afferent nerve fibros from the bladder and stomach and related their activity to contraction of the surrounding smooth muscle. He went on to isolate single afferent units which conduct at 1 m.p.s. and are presumably unmyelinated. With this useful technique, ho has worked on the smallest fibres from the skin which wero thought to be 'non-specific', and has shown that they are oxcited either by tension or by temperature changes. Dr. Iggo was elected to a Locke Research Fellowship in 1959. He spent a year at Canberra with Sir John Eccles working on the activation of Renshaw cells and allied problems and afterwards worked for a short time on temperature receptors with Prof. $H$. Hensel in the University of Marburg. He has had a varioty of exporionco both of teaching modical, dontal and physiology honours students and of full-time research. The Royal (Dick) School of Veterinary Studies is now moving its final-year departmonts to new buildings on the Bush Estate, where facilities have beon provided for teaching and research in connexion with farm animals. As a rosult, tho departmonts remaining in Edinburgh are now in a position to expand, and among the changes contemplated precedenco was givon to the development of the Department of Veterinary Physiology. 